\title{
Impact of hormonal and non-hormonal treatments on milk production and reproductive performance of lactating New Zeland White rabbits
}

\author{
Fahmy S. ${ }^{a}$, Hussein H. A. ${ }^{\text {b }}$, Farag B. F. ${ }^{{ }^{*}}$ \\ ${ }^{a}$ Department of animal productions, Faculty of Agriculture, Al-Azhar University, 71524 Assiut, Egypt \\ ${ }^{b}$ Department of Theriogenology, Faculty of Veterinary Medicine, Assiut University, 71526 Assiut, Egypt
}

\begin{abstract}
The present study aimed to determine the influence of equine chorionic gonadotropin (eCG), L-Carnitine (LC) and Royal jelly (RJ) treatments on milk production and subsequent reproductive performance of lactating NZW rabbits. A total 28 primiparous lactating New Zeland white (NZW) rabbits divided randomly into four groups ( 7 animals/ group): Group 1 (eCG group) on day 9 postpartum the females were treated with 50 IU eCG IM/ animal at $48^{\text {hrs }}$ before mating. Group 2 (LC group): the rabbits were given $50 \mathrm{mg} \mathrm{LC} / \mathrm{kg}$. BW/ day for 21 days orally starting at $24^{\text {hrs }}$ of parturition. Group 3 (RJ group) before mating the rabbits were given 100 $\mathrm{mg} \mathrm{RJ} / \mathrm{kg}$. BW/ day for 21 days orally starting at $24^{\text {hrs }}$ of parturition. Group 4 was Control group (without any treatment). The reproductive parameters including receptivity, conception and kindling rate as well as litter size and weight at weaning (LSW \& LWW) and pre-weaning mortality (PWM) were recorded. The results revealed that there were no significant differences in the number of services per conception, conception and kindling rate among eCG, LC, RJ and control groups. Milk production, LSW and PWM were significantly improved after LC or RJ compared to eCG and control. In conclusion, the non-hormonal treatment (LC or RJ) supplementation can improve milk production and this positively reflected on LSW, LWW and PWM.
\end{abstract}

Keywords: eCG, L-Carnitine, royal jelly, primiparous rabbits, milk production.

*Corresponding author: Farag B. F., 


\section{Introduction}

During the postpartum period, approximately $60 \%$ of lactating primiparous does are infertile and must highlighting on the negative effect of lactation on reproduction in such period (Lange and Schlolaut, 1989; Rebollar et al., 1992). In rabbit farms the most widely used hormone in lactating nonreceptive does is eCG (Rebollar et al., 2006), eCG injection two or three days before insemination has become very common in industrial management as this practice generally improves reproductive performance and it is simple to use (Gogol, 2004). Concerning of milk production after treatment with eCG, several works have consistently found that milk production is reduced in pregnant lactating rabbits versus lactating only (Hudson et al., 1996). LC can promote fatty acid and energy application by transporting long chain fatty acids across the inner mitochondria membrane for $\beta$-oxidation, thus enhance adenosine triphosphate (ATP) concentration (Vanella et al., 2000). Seleem et al. (2006) observed that the increase milk secretion and its yield in treated rabbits with LC as well as litter size and weight at birth significantly higher and preweaning mortality rate significantly lower than those of drank free LC water. Royal jelly (RJ) consists of a milky fluid secretion produced by the pharyngeal glands of bees 5 to 10 days old and has the primary function of feeding the queen, producing an individual anatomically and physiologically different from the workers, with development of reproductive capacity (Kohno et al., 2004). It has a complex composition water, proteins, lipids, carbohydrates, amino acids, mineral salts, vitamins, enzymes, hormones and natural antibiotics (Mărghitaş, 2008). Gimenez-Diaz et al. (2012) suggested that a single RJ (500 mg) injection increased overall reproductive performance of seasonal sheep breeds in the anestrus season. Also, Bonomi and Bonomi (2004) found that the addition of RJ was able to induce a significant improvement of milk yield, milk fat, and milk total protein and improved reproductive efficiency in dairy cattle. The aim of the present study was to investigate the influence of hormonal treatment (eCG) and non-hormonal treatments (RJ or LC) on milk production and subsequent reproductive performance of lactating NZW rabbits.

\section{Materials and methods}

\subsection{Animals and Management}

The present study was carried out at private farm in Mallawy, El-Minia government, Egypt (located at latitude of $28^{\circ} 07^{\prime} 6.00^{\prime \prime} \mathrm{N}$, longitude of $30^{\circ} 44^{\prime}$ 23.99" E and about 52 meters above sea level). The study was conducted on a total 28 primiparous lactating NZW rabbits aged between 5.5 - 6 months and with average weight of $(2936.25 \pm 19.54 \mathrm{gm})$. All rabbits were kept individually in suspended galvanized wire cages, provided with feeders and drinkers, receiving water, commercial feed (ALMARAI, 18\% protein).

\subsection{Experimental design and treatments}

The rabbits were divided randomly and equally into four experimental groups (7 animals / group) as follow: Group 1 (eCG group), on day 9 postpartum, the lactating 
females were treated with $50 \mathrm{IU}$ eCG (Gonaser, Hipra, Girona Spain) IM/animal at $48^{\text {hrs }}$ before the time of natural mating. Group 2 (L-Carnitine group), (Mepaco, Egypt) before mating, the rabbits were given $50 \mathrm{mg} \mathrm{LC/} \mathrm{kg}$. BW/day for 21 days orally starting at $24^{\text {hrs }}$ of parturition. Group 3 (Royal Jelly group), Egyptian fresh RJ was obtained from a local bee products company (KONOZ Co., Egypt), before mating, the rabbits were given $100 \mathrm{mg} \mathrm{RJ} / \mathrm{kg}$. BW/day for 21 days orally starting at $24^{\text {hrs }}$ of parturition. Group 4 (Control group), left without treatment and mated after day 21 of lactation. Milk yield was estimated after deprivation of the pups from suckling their mothers for $24^{\text {hrs }}$ according to Hudson and Distel, (1982), when the kits started to consume solid feed, from day 18 of lactation onwards, the kits housed in a separated cage to allow both the milk yield determination as well as the normal development of the kits according to Fortun-Lamothe et al. (2000), the pups were weighted before and after suckling, the increase in pups weight was used as the doe milk yield (Seleem et al., 2006). In the all previous groups (G1, G2, G3 and G4) natural mating by fertile bucks was done. At kindling, litter size and weight at birth were recorded. Litter size and weight at weaning ((LSW, LWW, 28 days of age) as well as Pre weaning mortality (PWM) were recorded per doe.

2.3 The items were recorded for each treatment group

- Sexual receptivity rate, conception, number services per conception, kindling rate and litter size at birth.
- Milk yield per doe (total and daily /gm).

- $\quad$ Litter size and weight at 28 days of lactation (weaning) and Pre weaning mortality per doe were recorded.

\subsection{Statistical analysis}

All data were analyzed by Statistical Package for the Social Sciences (SPSS, version 20) software and presented as mean \pm SE. Significant differences among the groups (number services/conception, milk production, LSB, LSW, LWW, PWM and biochemical parameters) was performed by one-way ANOVA followed by posthoc Duncan test (Duncan, 1955). Receptivity, conception and kindling rate were compared between treatment groups using the chi-square test. The statistical significant differences were accepted at $(\mathrm{P}<0.05)$.

\section{Results and Discussion}

\subsection{Reproductive performance of} lactating New Zeland white rabbits

The present results showed that there were no significant differences of receptivity, number services per conception, conception and kindling rate among eCG, LC, RJ and control groups (Table 1). The results regarding to eCG effects on reproductive activity of lactating rabbits in coincided with Quintela et al. (2001) where they found that no significant differences of eCG treatment on receptivity or kindling rate in lactating rabbits. Also, Theau-Cle'ment 
et al. (2008) showed that no significant effect of this hormone (eCG) in the fertility of primiparous does. To our knowledge there are no available studies at yet about the effect of LC or RJ treatment on the receptivity, conception and kindling rates in lactating rabbits, however, the obtained results indicated that the application of LC or RJ to rabbits during lactation had not negative effects on reproductive activity and tended to have higher receptivity and conception rate addition to decrease services index compared to untreated does.

Table (1): Effect of hormonal (eCG) and non-hormonal (LC, RJ) treatments on reproductive performance of lactating primiparous New Zeland white rabbits $(n=7$; Mean \pm SM).

\begin{tabular}{lccccc}
\hline \multirow{2}{*}{ Groups } & \multicolumn{5}{c}{ Reproductive performance } \\
\cline { 2 - 6 } & $\begin{array}{c}\text { Receptivity } \\
\%(\mathrm{n})\end{array}$ & $\begin{array}{c}\text { NO Services/ } \\
\text { conception }\end{array}$ & $\begin{array}{c}\text { Conception } \\
\%(\mathrm{n})\end{array}$ & $\begin{array}{c}\text { K Kindling } \\
\%(\mathrm{n})\end{array}$ & LSB \\
\hline eCG & $85.71(6 / 7)$ & $1.25 \pm 0.25$ & $66.67(4 / 6)$ & $100(4 / 4)$ & $7.00 \pm 0.40^{\mathrm{a}}$ \\
\hline $\mathrm{LC}$ & $85.71(6 / 7)$ & $1.20 \pm 0.20$ & $83.33(5 / 6)$ & $100(5 / 5)$ & $6.80 \pm 0.37^{\mathrm{a}}$ \\
\hline $\mathrm{RJ}$ & $85.71(6 / 7)$ & $1.50 \pm 0.28$ & $66.67(4 / 6)$ & $100(4 / 4)$ & $5.50 \pm 0.28^{\mathrm{b}}$ \\
\hline Control & $71.43(5 / 7)$ & $1.66 \pm 0.33$ & $60.00(3 / 5)$ & $100(3 / 3)$ & $5.00 \pm 0.57^{\mathrm{b}}$ \\
\hline Sig & $\mathrm{NS}$ & $\mathrm{NS}$ & $\mathrm{NS}$ & $\mathrm{NS}$ & 0.01 \\
\hline Different & superscript letters indicate significance & within the same column $(\mathrm{p}<0.01)$. & $\mathrm{NS}=\mathrm{No}$ \\
Significant. LSB = Litter Size at Birth.
\end{tabular}

\subsection{Litter size at birth (after lactation)}

The results showed that, litter size at birth (LSB) in eCG and LC groups significantly higher than that in RJ and control groups, were $(7.00 \pm 0.40$ and $6.80 \pm 0.37$ VS $5.50 \pm 0.28$ and $5.00 \pm 0.57$, respectively; $\mathrm{P}<0.01)$ (Table 1$)$. Increase of the litter size at birth after LC treatment in lactating rabbits may be due to enhancement of ovarian follicles prior mating as well as increase ovulation rate after mating. Litter size is determined by ovulation rate, fertilization and/or prenatal survival in rabbits (Blasco et al., 1993; Belabbas et al., 2016). The current results agreed with the finding by Rebollar et al. (2006) who recorded that eCG treatment increased prolificacy (more kits born) in lactating does compared to controls. Also,
Bonanno et al. (1990) showed that eCG provoked significant follicular growth, which could explain a higher ovulation rate and more litters at birth. Many studies observed that the application of LC prior mating improved follicular growth in mice (Miyamoto et al., 2010) and ewes (El-Shahat and Abo-Elmaaty, 2010) and increased ovulation rate in rabbits (Abdel-Khalek et al., 2016).

\subsection{Milk production}

Total milk yield during lactation period increased significantly $(\mathrm{p}<0.01)$ in LC VS RJ and was higher than that in control and eCG groups $(2950.00 \pm 79.07$ VS $2636.80 \pm 40.28$ VS $2297.16 \pm 67.21$ and $2172.66 \pm 129.65 / \mathrm{gm} /$ doe, respectively) (Table 2). Likewise, the daily milk yield 
increased significantly $(\mathrm{p}<0.01)$ in LC VS $\mathrm{RJ}$ and higher than that in control and eCG groups (105.35 \pm 2.82 VS $94.17 \pm 1.43$ VS $82.04 \pm 2.40$ and $77.59 \pm 4.63 / \mathrm{gm} / \mathrm{doe}$, respectively). Increase milk yield (total and daily) in rabbits treated with LC may be due to the positive activities of $\mathrm{LC}$ as antioxidant on balance of energy, metabolic and mammary glands health during lactation. Eder et al. (2004) observed that sows supplemented with LC had larger and more active mammary glands than control animals. Furthermore, Scholz et al. (2014) recorded that LC improved metabolic health during lactation and showed a trend of improving milk production in dairy cows. The present results coincided with those reported by Seleem et al. (2006), where they observed increase milk secretion yield in treated rabbits with L-Carnitine. Furthermore, Pirestani and Aghakhani (2018) found that, LC had favorable effect on milk production; this can be attributed to the positive effects of LC on reducing the negative balance of energy and protein production. There are no available studies at yet about the effect of RJ treatment on milk production in rabbits, the increase in milk yield after RJ treatment may be due to the complex components found in RJ as a source of nutrients which might be involved in metabolic pathways and tissue synthesis, RJ have vasodilative activities, have antioxidant effects and increase energy production. It reported that RJ has been demonstrated to possess several pharmacological activities in experimental animals, as metabolic and antioxidant effects (Liu et al., 2008) and have vasodilative activities (Shinoda et al., 1978) which might increase blood flow to mammary glands and improvement its functions. A number of workers outlined the effects of RJ treatments in other species. Bonomi and Bonomi (2004) found that the addition of royal jelly was able to induce a significant improvement of milk yield in dairy cattle. Also, El-Tarabany et al. (2019) recorded that the ewes supplemented with RJ had higher in daily milk yield than untreated ewes.

Table 2: Effect of hormonal (eCG) and non-hormonal (LC, RJ) treatments on milk production, LSW, LWW and PWM of lactating NZW rabbits (Mean \pm SEM).

\begin{tabular}{lccccc}
\hline Groups & Total milk yield /gm & Daily milk yield /gm & LSW & LWW & PWM \\
\hline $\mathrm{eCG}$ & $2172.66 \pm 129.65^{\mathrm{c}}$ & $77.59 \pm 4.63^{\mathrm{c}}$ & $3.57 \pm 0.29^{\mathrm{b}}$ & $372.41 \pm 16.26^{\mathrm{c}}$ & $2.71 \pm 0.28^{\mathrm{a}}$ \\
\hline LC & $2950.00 \pm 79.07^{\mathrm{a}}$ & $105.35 \pm 2.82^{\mathrm{a}}$ & $5.57 \pm 0.42^{\mathrm{a}}$ & $428.94 \pm 11.84 \mathrm{a}^{\mathrm{b}}$ & $0.71 \pm 0.28^{\mathrm{b}}$ \\
\hline RJ & $2636.80 \pm 40.28^{\mathrm{b}}$ & $94.17 \pm 1.43^{\mathrm{b}}$ & $5.28 \pm 0.35^{\mathrm{a}}$ & $463.18 \pm 17.09^{\mathrm{a}}$ & $1.14 \pm 0.34^{\mathrm{b}}$ \\
\hline Control & $2297.16 \pm 67.21^{\mathrm{c}}$ & $82.04 \pm 2.40^{\mathrm{c}}$ & $4.14 \pm 0.26^{\mathrm{b}}$ & $386.47 \pm 24.07^{\mathrm{bc}}$ & $2.71 \pm 0.42^{\mathrm{a}}$ \\
\hline Sig & 0.01 & 0.01 & 0.01 & 0.01 & 0.01 \\
\hline
\end{tabular}

Different superscript letters indicate significance within the same column $(\mathrm{p}<0.01)$. LSW $=$ Litter Size at Weaning. LWW = Litter Weight at Weaning (Mean individual). PWM = Pre Weaning Mortality.

The results regarding to eCG effect on milk production in coincide with Rebollar et al. (2008) reported that the eCG when administration at day 9 postpartum lead to decrease in PRL concentrations. The rabbits treated with eCG at day 9 
postpartum (day 9 of lactation) showed lower in milk production compared to other group, this decreased may be due to concurrent of lactation with pregnancy. This group treated with eCG at day 9 postpartum and mated at day 11 postpartum and the pregnancy was done (four does came pregnant from total group; Table 1) during lactation period. The decline in milk yield due to the gestation overlapping is a result of the pregnancy requirements that consistently increase with the exponential fetal development (Parigi-Bini and Xiccato, 1998).

\subsection{Litter size and weight at weaning and preweaning mortality}

At the end of lactation period (28 days) Litter size and weight at weaning (LSW, LWW) and preweaning mortality (PWM) were recorded and showed in Table (2). LSW was significantly $(\mathrm{p}<0.01)$ higher in LC and RJ groups than that in control and eCG groups (5.57 \pm 0.42 and $5.28 \pm 0.35 \mathrm{VS}$ $4.14 \pm 0.26$ and $3.57 \pm 0.29$, respectively). LWW was significantly $(\mathrm{p}<0.01)$ higher in RJ than in control and eCG groups $(463.18 \pm 17.09$ VS $386.47 \pm 24.07$ and $372.41 \pm 16.26 / \mathrm{gm}$, respectively), but no significant difference compared to LC group (428.94 $\pm 11.84 / \mathrm{gm})$ (Table 2). Preweaning mortality (PWM) was significantly $(p<0.01)$ lower in LC and RJ groups than in eCG and control groups $(0.71 \pm 0.28$ and $1.14 \pm 0.34$ VS $2.71 \pm 0.28$ and $2.71 \pm 0.42 /$ doe, respectively; Table 2). This mean there was improvement in the fetal viability in both LC and RJ groups. This improvement in LSW, LWW and PWM in LC and RJ groups may be attributed to the high milk production resulting of these treatments (as showed in Table 2). There was a positive correlation between litter size and milk yield in rabbits (Lebas et al., 1997; Rommers et al., 2001), growth and survival of rabbit kits depend exclusively on the doe's milk production as a first food for the newly born offspring (Kapadiya et al., 2016). The results recorded by Jimoh and Ewuola (2017) indicated that the high milk yield of rabbit does increased survival rate and average litter weight at weaning. Also, Khalil (1980) acknowledged that decline in mortality due to improvement in maternal care through the does' capacity to produce adequate milk and suckle her young. The results regarding to the positive effect of LC in agreement with those reported by Seleem et al. (2006), where they found that the pre-weaning mortality significantly lower in rabbit does supplemented with LC than control. Furthermore, Ramanau et al. (2004) found that the piglets of sows supplemented with LC grew faster during the suckling period than piglets of control sows; this suggests that this effect might be due to a higher milk yield and an increased transfer of energy and nutrients from the sow to the piglets with the milk. Addition to the positive effect of RJ on milk production, increase litter size and weight at weaning and decrease PWM in lactating rabbits treated with RJ may be also due to the positive effect of RJ on milk composition. Early live ability and growth performances of newborn rabbits are closely related to the quantity and quality of the milk ingested (Szendrö and Maertens, 2001). El-Tarabany et al. 
(2019) recorded that the supplementation of RJ improves daily milk yield and the contents of milk (proteins, fats and total solids) in lactating Ossimi ewes. There were not improve in LSW, LWW and PWM of lactating rabbits treated with $\mathrm{eCG}$, this may be due to the negative effect of eCG on milk production (Table 2). These results in agreement with those reported by Maertens and Luzi (1995), where they observed that eCG does not improve the litter size and weight at weaning. Furthermore, Mehaisen and Abbas (2014) found that the number of weaned kits significantly decreased in eCG group (3.8 kits) in comparison with control group (6.1 kits).

\section{Conclusions}

In conclusion, the non-hormonal treatment (LC or RJ) supplementation can improve milk production and this positively reflected on LSW, LWW and PWM, as well as LC or RJ hadn't negative effect on reproductive performance of primiparous NZW rabbits. The application of eCG at day 9 postpartum (semi-intensive rhythm) causes decline milk production and this negatively reflected on LSW, LWW and PWM.

\section{References}

Abdel-Khalek, A. E., El-Ratel, I. T., Wafa, W. M., El-Nagar, H. A., Younan, G. E. and Fouda, S. F.
(2016), "Effect of pre-conception coenzyme Q10 and L-carnitine treatments on ovulatory response, genital characteristics and in vitro embryo characteristics in rabbits", Asian Journal Animal Veterinary Advances, Vol. 11, pp. 53-59.

Belabbas, R., García, M. L., Ainbaziz, H., Berbar, A., Zitouni, G., Lafri, M., Bouzouan, M., Merrouche, R., Ismail, D., Boumahdi, Z., Benali, N. and Argente, M. J. (2016), "Ovulation rate and early embryonic survival rate in female rabbits of a synthetic line and a local algerian population", World Rabbit Science, Vol. 24, pp. 275-282.

Blasco, A., Bidanel, J. P., Bolet, G., Haley, C. S. and Santacreu, M. A. (1993), "The genetics of prenatal survival of pigs and rabbits: a review", Livestock Production Science, Vol. 37, pp. 1-21.

Bonanno, A., Budetta, G., Alabiso, M. and Alicata, M. L. (1990), "Effects of PMSG and GnRH treatment on the ovulatory efficiency of the rabbits", Acta Medicin Vetrinary Journal, Vol. 36, pp. 441-451.

Bonomi, A. and Bonomi, B. M. (2004), "The use or royal jelly in dairy cattle feeding; Effects on productive and reproductive efficiency", Rivista di Scienza dell'Alimentazione, Vol. 33 No. 4, pp. 239-249.

Duncan, D. B. (1955), "The Multiple Range and Multiple F Test", 
Biometrics, Vol. 11, pp. 1-42.

Eder, K., Ramanau, A., Felgner, J. and Kluge, H. (2004), "Effect of Lcarnitine supplementation in sows on milk yield and fat mobilization during lactation in case of energetic deficit $8^{\text {th }}$ session, Pigs and Poultry Nutrition, Martin Luther University Halle-Wittenberg, Halle, Germany, pp. 90-92.

ElShahat, K. H. and Abo-El maaty, A. M. (2010), "The effect of dietary supplementation with calcium salts of long chain fatty acids and/or 1carnitine on ovarian activity of Rahmani ewes", Animal Reproduction Science, Vol. 117, pp. 78-82.

ElTarabany, M. S., El-Tarabany, A. A., Atta, M. A., Ahmed-Farid, O. A., and Mostafa, M. M. (2019), "Effect of royal jelly on milk composition and blood biochemical parameters in lactating ewes" The Journal of Agricultural Science, Vo. 157, pp. 176-181.

Fortun-Lamothe, L., Rochambeau, H., Lebas, F. and Tudela, F., (2000), "Influence of the number of suckling young on reproductive performance in intensively reared rabbits does", In: Proceedings of the $7^{\text {th }}$ World Rabbit Congress, Valencia (Spain), Vol. A, pp. 125-132.

Gimenez-Diaz, C., Emsen, B., Emsen, E., Kutluca, M. and Koycegiz, F. (2012), "Improved reproductive response of sheep in intrauterine insemination programwith the use of royal jelly", African Journal Biotechnology, Vol. 11, pp. 1251812521.

Gogol, P. (2004), "Studies on the effectiveness of rabbit synchronization in rabbits", Zoot Journal, Vol. 2, pp. 41-44.

Hudson, R. and Distel, H. (1982), "The pattern of behavior of rabbit pups in the nest", Behaviour Journal, Vol. 79, pp. 255-271.

Hudson, R., Bilkö, A. and Altbäcker, V. (1996), "Nursing, weaning and the development of independent feeding in the rabbit (Oryctolagus cuniculus)", Zeitschrift Fur Säugetierk, Vol. 61, pp. 39-48.

Jimoh, O. A. and Ewuola, E. O. (2017), "Milk yield and kit development of four breeds of rabbit in Ibadan, Nigeria", Journal of Animal Science and Technology, Vol. 59, pp1-7.

Kapadiya, D. B., Prajapati, D. B., Jain, A. K., Mehta, B. M., Darji, V. B. and Aparnathi, K. D. (2016), "Comparison of Surti goat milk with cow and buffalo milk for gross composition, nitrogen distribution and selected minerals content", Vetrinary World Journal, Vol. 9, pp. 710-716.

Khalil, M. H. (1980), Genetic and environmental studies on some productive traits in rabbits, MSc. 
Thesis, Faculty Agriculture, Zagazig University (Banha Branch), Moshtohor, Egypt.

Kohno, K., Okamoto, I., Sano, O., Arai, N., Iwaki, K., Ikeda, M. and Kurimoto, M. (2004), "Royal jelly inhibits the production of proinflammatory cytokines by activated macrophages", Bioscience, Biotechnology and Biochemistry, Vol. 68, pp. 138-145.

Lange, K. and Schlolaut, W. (1989), "The influence of post-partum insemination on litter size and growth of New Zeland White rabbit", Proceedings of the $4^{\text {th }}$ World Rabbit Congress, Vol. 2, pp. 130-140.

Lebas, F., Coudert, P., Rochambeau, D. and Thébault, R. G. (1997), The Rabbit Husbandry, Health and Production, Food and Agriculture Organization of the United Nations (FAO), Rome, Italy.

Liu, J. R., Yang, Y. C., Shi, L. S. and Peng, C. C. (2008), "Antioxidant properties of royal jelly associated with larval age and time of harvest", Journal of Agricultural and Food Chemistry, Vol. 56, pp. 1144711452.

Maertens, L. and Luzi, F. (1995), "Note concerning the effect of PMSG stimulation on the mortality rate at birth and the distribution of litter size in artificially inseminated does", World Rabbit Science, Vol.
3, pp. 57-61.

Mărghitaş, L. A. (2008), "Beekeeping products and their main therapeutic properties", in Mărghitaş, L. A. (Second ed.), Bees and their products, Ceres, Bucharest, Romania, pp. 280-378.

Mehaisen, G. M. K. and Abbas, A. O. (2014), "Effect of hormonal eCG treatment versus rearing-fasting program on embryo recovery, reproductive performance and hormonal profile in nulliparous rabbit does", Egyptian Journal of Animal Production, Vol. 51, pp. 27 34.

Miyamoto, K., Sato, E. F., Kasahara, E., Jikumaru, M., Hiramoto, K., Tabata, H., Katsuragi, M., Odo, S., Utsumi, K. and Inoue, M. (2010), "Effect of oxidative stress during repeated ovulation on the structure and functions of the ovary, oocytes, and their mitochondria", Free Radical Biology and Medicine, Vol. 49, pp. 674-681.

Parigi Bini, R. and Xiccato, G., (1998), "Energy metabolism and requirements", in De Blas and Wiseman (eds.), The nutrition of the Rabbit, CABI Publishing, Wallingford, UK, pp.103-131.

Pirestani, A. and Aghakhani, M. (2018), "The effects of rumen-protected choline and l-carnitine supplementation in the transition period on reproduction, production, 
and some metabolic diseases of dairy cattle", Journal of Applied Animal Research, Vol. 46, pp. 435440.

Quintela, L., Peña, A., Barrio, M., Vega, M., Diaz, R., Maseda, F. and Garcia, P. (2001), "Reproductive performance of multiparous rabbit lactating does: effect of lighting programs and PMSG use", Reproduction Nutrition Development, Vol. 41, pp. 247-257.

Ramanau, A., Kluge, H., Spilke, J. and Eder, K. (2004), "Supplementation of sows with L-carnitine during pregnancy and lactation improves growth of the piglets during the suckling period through increased milk production", Journal of Nutrition, Vol. 134, pp. 86-92.

Rebollar, P. G., Milane's, A., Pereda, N., Milla'n, P., Cano, P. and Esquifino, A. I. (2006), "Oestrus synchronisation of rabbit does at early postpartum by doe-litter separation or eCG injection: Reproductive parameters and endocrine profiles", Animal Reproduction Science, Vol. 93, pp. 218-230.

Rebollar, P. G., Ubilla, E., Alvariño, J. M., Illera, J. C. and Silván, G. (1992), "Effect of the level of sexual receptivity on plasma estradiol and the ovulatory response during the postpartum period in the rabbit", Revista Española de Fisiología Journal, Vol. 48, pp. 13-18.
Rebollar, P.G., Bonanno, A., Di Grigoli, A., Tornambè, G. and Lorenzo, P. L. (2008), "Endocrine and ovarian response after a 2-day controlled suckling and eCG treatment in lactating rabbit does", Animal Reproduction Science, Vol. 104, pp. 316-328.

Rommers, J. M., Meijerhof, R., Noordhuizen, J. P. T. M. and Kemp, B. (2001), "Effect of different feeding levels during rearing and age at first insemination on body development, body composition and puberty characteristics of rabbit does", World Rabbit Science, Vol. 9, pp. 101-108.

Scholz, H., Heimendahl, E. V., Menn, F. and Ahrens, A. (2014), "Application of Protected L-Carnitine in dairy Cows during Transition and High Lactation Period", Global Journal of Science Frontier Research, Vol. 14, pp. 41-46.

Seleem, T. S. T., Abd El-Motaal,A. E. M. and El-Kholy, K. H. (2006), "Effect of L-carnitine preparation in drinking water on some productive and reproductive performance of NZW rabbits", Journal of Biological Chemistry Environment Science, Vol. 1, pp. 14.

Shinoda, M., Nakajin, S., Oikawa, T., Sato, K., Kamogawa, A. and Akiyama, Y. (1978), "Biochemical studies on vasodilative factor in royal jelly", Yakugaku Zasshi, Vol. 98, pp. 139-145. 
Szendrö, Z. S. and Maertens, L. (2001), "Maternal effect during pregnancy and lactation in rabbits", review, Acta Agraria Kaposváriensis, Vol. 5, pp. 1-21.

Theau-Cle'ment, M., Lebas, F., Beckers, J. F., and Drion, P. V. (2008), "volution of anti-eCG antibodies in response to eCG doses and number of injections. Relationship with productivity of rabbit does", Animal Journal, Vol. 2, pp. 746-751.
Vanella, A., Russo, A., Acquaviva, R., Campisi, A., Di Giacomo, C. and Sorrenti, V. (2000), "L-propiony lcarnitine as superoxide scavenger, antioxidant, and DNA cleavage protector", Cell Biology and Toxicology, Vol. 16, pp. 99-104. 